\title{
Introduction: Menstruation as Narrative
}

\author{
Elizabeth Arveda Kissling
}

Personal stories, urban legends, literature, media representations, and other kinds of narratives provide means of sharing information about menstruation, including what women and other menstruators should and should not do during their periods. For instance, no book has had more impact upon pubescent North American girls than Judy Blume's 1970 Are You There God? It's Me, Margaret. Girls growing up in the 1970s and onward, in a cultural milieu where they were encouraged to silence their questions and hush their bodies, had a protagonist with whom to identify and empathize. While Margaret has been updated to reflect changes in menstrual products, little has changed with respect to norms of menstrual silence.

In conceptualizing menstruation as narrative, we recognize story as a fundamental element of human culture. Any situation is a story, "a humanly constructed set of meanings that make sense out of phenomena" (Gadow 1994, 306). Every culture throughout history has used narratives to process, share, and remember life experience (Gottschall 2012; Hsu 2008). That includes experiences and knowledge of menstruation, menarche, and menopause. Stories-whether the personal narratives of menarche instruction passed from mother to daughter or sister to sister or the scripted, sterile, wooden speeches of menstrual education films of the mid-twentieth century-are more than language. Indeed, they are not merely words or symbols (Reinsborough and Canning 2010). The words, heeded and performed, become actions. Stories do more than describe the world-stories make the world. They are more than mere discursive structures; it is only through new narratives that extant cultural narratives can be reframed and altered. Activists and advertisers know this (Ganz 2001; Couto 1993; Kissling 2018); so do politicians and filmmakers (Day 2011).

Stories take many different forms. Although many Westerners conceptualize narratives as linear-with a beginning, middle, end, and point - that 
structure is by no means universal. For example, there is the kernel story, a brief, unstructured capsule version or reference to a story identified in (Kalčik's 1975) study of women's personal experience narratives; and the interactive call-and-response practice common in African-American oratory, musical, and literary traditions (Asante 1998; Callahan 2001). And no general narrative can speak for everyone, especially when the goal is resisting and revising dominant narratives, such as the limited biomedical narratives (Gadow 1994) of the menstrual cycle. It is unsurprising, therefore, that research and exploration of menstruation narratives takes many forms and occurs both across and outside many academic disciplines.

The variety of approaches, methods, linguistic styles, national origins, and phases of menstrual life cycle in this section indicates the great breadth and depth of menstrual narratives and narrative analysis. Some stories are told through traditional sociological qualitative methods, collecting stories from interviews with community members and analyzing the stories with interpretive feminist frameworks informed by the participants' views. Among these are stories shared in private-for example, those revealed to Rothschild and Piya (Chapter 66) that were passed across generations of women in Nepal, and those collected by Singh and Sivakami (Chapter 70) that were shared among women in India. Other stories move between intimate partners, as those seen in Fahs' research (Chapter 69) who were discussing and/or practicing period sex.

Sharing stories through media is another narrative form; some are shared on screens in schools, seen in Ghanoui's analysis of twentieth-century U.S. menstruation education films (Chapter 67), while others are shared globally, like the menstrual stories of young Danish YouTubers presented in Andreasen's discussion of monstrous menstruators (Chapter 65). These media narratives are examined through critical lenses, considering historical contexts, ideology, and performance.

Some stories challenge the biomedical menstruation narratives that exclude and distort-for example, the growing awareness among activists, academics, and, increasingly, the general public that 'not only women menstruate and not all women menstruate,' which is articulated in Rydström's analysis of trans menstruation (Chapter 68). What some call 'queering menstruation' is gaining traction in various social, commercial, educational, and political spaces, as Guilló-Arakistain's challenge to menstrual normativity asserts (Chapter 63). While these two pieces incorporate ethnographic material, they also draw upon the language and methods of critical theory to construct new stories and definitions of menstruators. Bobel and Fahs (Chapter 71) also use a feminist, critical approach in their overview of menstrual activism in the United States, building a political history to ground their call for action.

Still other stories are told by voices that provide an unexpected perspective. Berkley Conner combines feminism and rhetorical analysis to show how period stories can be used as political tools in the online 'Periods for Pence' 
campaign (Chapter 64). The varied personal experience narratives collected by Perianes (Chapter 72) remind us that family stories can serve as instruction, warning, and even entertainment.

We hope the menstruation narratives collected here-and their analyseseducate and entertain you, and in some cases warn you or inspire you.

\section{REFERENCES}

Asante, Molefi K. 1998. The Afrocentric Idea, Revised and Expanded. Philadelphia: Temple University Press.

Callahan, John. 2001. In the African-American Grain: Call-and-Response in Twentieth-Century Black Fiction. Urbana: University of Illinois Press.

Couto, Richard A. 1993. "Narrative, Free Space, and Political Leadership in Social Movements." The Journal of Politics 55 (1): 57-79.

Day, Amber. 2011. Satire and Dissent. Bloomington: Indiana University Press.

Gadow, Sally. 1994. "Whose Body? Whose Story? The Question about Narrative in Women's Health Care." Soundings 77 (3-4): 295-307.

Ganz, Marshall. 2001. "The Power of Story in Social Movements." Paper presented at Annual Meeting of the American Sociological Association, Anaheim, CA.

Gottschall, Jonathan. 2012. The Storytelling Animal: How Stories Make Us Human. Boston, MA: Houghton-Mifflin.

Hsu, Jeremy. 2008. "The Secrets of Storytelling: Our Love for Telling Tales Reveals the Workings of the Mind." Scientific American Mind 19 (4). Retrieved from EBSCO Academic Search Complete.

Kalčik, Susan. 1975. ““... Like Ann's Gynecologist or the Time I Was Almost Raped': Personal Narratives in Women's Rap Groups." The Journal of American Folklore 88 (347): 3-11.

Kissling, Elizabeth Arveda. 2018. From a Whisper to a Shout: Abortion Activism and Social Media. London: Repeater Books.

Reinsborough, Patrick, and Doyle Canning. 2010. Re:Imagining Change. Oakland, CA: PM Press. 
Open Access This chapter is licensed under the terms of the Creative Commons Attribution 4.0 International License (http://creativecommons.org/licenses/ by $/ 4.0 /)$, which permits use, sharing, adaptation, distribution and reproduction in any medium or format, as long as you give appropriate credit to the original author(s) and the source, provide a link to the Creative Commons license and indicate if changes were made.

The images or other third party material in this chapter are included in the chapter's Creative Commons license, unless indicated otherwise in a credit line to the material. If material is not included in the chapter's Creative Commons license and your intended use is not permitted by statutory regulation or exceeds the permitted use, you will need to obtain permission directly from the copyright holder. 